\title{
First Insight into Microbiome Profiles of Myrmecophilous Beetles and Their Host, Red Wood Ant Formica polyctena (Hymenoptera: Formicidae)—A Case Study
}

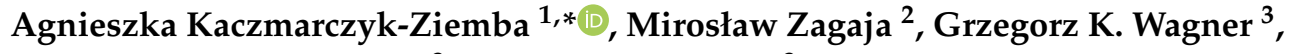 \\ Ewa Pietrykowska-Tudruj ${ }^{3}$ and Bernard Staniec ${ }^{3}$ \\ 1 Department of Genetics and Biosystematics, Faculty of Biology, University of Gdansk, Wita Stwosza 59, \\ 80-308 Gdansk, Poland \\ 2 Isobolographic Analysis Laboratory, Institute of Rural Health, Jaczewskiego 2, 20-090 Lublin, Poland; \\ zagaja.miroslaw@imw.lublin.pl \\ 3 Department of Zoology and Nature Protection, Maria Curie-Sklodowska University, Akademicka 19, \\ 20-033 Lublin, Poland; grzegorz.wagner@poczta.umcs.lublin.pl (G.K.W.); \\ ewa.pietrykowska-tudruj@poczta.umcs.lublin.pl (E.P.-T.); bernard.staniec@poczta.umcs.lublin.pl (B.S.) \\ * Correspondence: agnieszka.kaczmarczyk-ziemba@ug.edu.pl; Tel.: +48-58-5236082
}

Received: 23 December 2019; Accepted: 17 February 2020; Published: 19 February 2020

\begin{abstract}
Formica polyctena belongs to the red wood ant species group. Its nests provide a stable, food rich, and temperature and humidity controlled environment, utilized by a wide range of species, called myrmecophiles. Here, we used the high-throughput sequencing of the 16S rRNA gene on the Illumina platform for identification of the microbiome profiles of six selected myrmecophilous beetles (Dendrophilus pygmaeus, Leptacinus formicetorum, Monotoma angusticollis, Myrmechixenus subterraneus, Ptenidium formicetorum and Thiasophila angulata) and their host F. polyctena. Analyzed bacterial communities consisted of a total of 23 phyla, among which Proteobacteria, Actinobacteria, and Firmicutes were the most abundant. Two known endosymbionts-Wolbachia and Rickettsia-were found in the analyzed microbiome profiles and Wolbachia was dominant in bacterial communities associated with F. polyctena, M. subterraneus, L. formicetorum and P. formicetorum (>90\% of reads). In turn, M. angusticollis was co-infected with both Wolbachia and Rickettsia, while in the microbiome of T. angulata, the dominance of Rickettsia has been observed. The relationships among the microbiome profiles were complex, and no relative abundance pattern common to all myrmecophilous beetles tested was observed. However, some subtle, species-specific patterns have been observed for bacterial communities associated with D. pygmaeus, M. angusticollis, and T. angulata.
\end{abstract}

Keywords: $16 \mathrm{~S}$ rRNA; Formica polyctena; microbiome; myrmecophile; Rickettsia; Wolbachia

\section{Introduction}

Myrmecophiles (or ant associates) are organisms that are dependent on various ant species, at least during part of their lifecycle. They are able to penetrate and survive inside the heavily defended ants' nests [1-3]. A very large number of myrmecophiles are insects, mainly beetles [3,4]. Besides them, there are myrmecophiles, among other, often distant, systematic groups, including flies, crickets, butterflies, bristletails, millipedes, isopods, mites, spiders, aphids, scale insects, wasps, and even snails and snakes [1]. Myrmecophiles include both the most morphologically and behaviorally specialized animals as well as poorly specialized ones. As a consequence of interactions with ants, they adopted a variety of unique features to evade or avoid ant attacks [1,5]. Therefore, myrmecophiles 
are very attractive research subjects in studies on their systematic differentiation, ecology, life history, and phylogeny [6-10].

Despite the great interest in biology and ecology of myrmecophiles, studies on the microorganisms associated with them, the potential similarities of microbiome profiles of ants and their associates, and the probable horizontal transfer of microorganisms among insects inhabiting or visiting ants nests are limited. A recent study focusing on the microbiota of several honeydew-producing Prociphilus aphids and Rhizoecus mealybugs farming by Brachymyrmex and Lasius ants revealed a phylogenetic signal in the microbiomes of trophobionts [11]. Each selected species, despite being farmed by the same ants, harbored specific strains of identified endosymbionts (Buchnera, Tremblaya, Sodalis, and Serratia). That result was explained by the strict vertical transmission of endosymbionts between generations of trophobionts. In contrast, tested Brachymyrmex and Lasius microbiome was possibly shaped by host's partnerships, and ant-bacteria associations were subject to horizontal transmission or social transmission within colonies [11]. Bacterial communities were also profiled for socially parasitic Megalomyrmex ants and their fungus-growing ant hosts from the genera Cyphomyrmex, Trachymyrmex, and Sericomyrmex [12]. Performed analyses showed that social parasites and their hosts shared a subset of bacterial symbionts (Entomoplasmatales, Bartonellaceae, Acinetobacter, Wolbachia, and Pseudonocardia) and that Entomoplasmatales and Bartonellaceae can co-infect specifically associated combinations of hosts and social parasites with identical $16 \mathrm{~S}$ rRNA genotypes. Moreover, obtained results implied that cohabiting ant social parasites and hosts may obtain functional benefits from bacterial symbiont transfer even when they are not closely related.

Although studies by Ivens et al. (2018) [11] and Liberti et al. (2015) [12] shed light on the microbiome profiles of some ants associates, there are still a lot of ambiguities. Because of hidden life, the distribution and abundance of myrmecophiles are unclear and likely underestimated. Nevertheless, it is thought that beetles consist of the richest and the most diverse group among ant associates [3]. Although the exact numbers of myrmecophilous beetles associated with particular ants are usually barely estimated, in some cases (e.g., for ants representing Formica genus), this group has been better recognized.

The ants of the genus Formica are the widespread and significant component of forest ecosystems. They influence soil qualities and the presence of some plant species. Formica ants also have a strong influence on surrounding zoocenosis [13]. Within the Formica genus, one may distinguish the Formica rufa group (commonly called red wood ants). All red wood ant's species are morphologically very similar and show high intraspecific variability [14]. Therefore, they belong to the most studied ant species in Europe with respect to their biology, ecology, and phylogeny [14-18]. Furthermore, these ants build complex nests with a stable level of temperature and humidity, as well as a constant and diversified food resource, which are the optimal place to live for a great number of myrmecophilous insects. For example, as many as 56 myrmecophilous beetle species have been found in the nests of representatives of the genus Formica [7]. Bacterial communities associated with these species have not been investigated exhaustively, and the tri-party relationships occurring among host ant, myrmecophilous beetle, and associated bacterial communities have not been investigated yet for Formica representatives.

In the present study, our main goal was to shed light on complex tripartite relationships among F. polyctena, selected myrmecophilous beetles commonly inhabiting its nest and microbial communities associated with all species tested. We selected six beetle species belonging to five different families: Thiasophila angulata (Erichson, 1837), Leptacinus formicetorum (Märkel, 1841) (Staphylinidae), Dendrophilus pygmaeus (Linnaeus, 1758) (Histeridae), Monotoma angusticollis (Gyllenhal, 1877) (Monotomidae), Ptenidium formicetorum (Kraatz, 1851) (Ptiliidae) and Myrmechixenus subterraneus (Chevrolat, 1835) (Tenebrionidae). All selected species are commonly found inside F. polyctena nests, but they are rather unspecialized in the level of integration into colony $[19,20]$. Two representatives of Staphylinidae: Thiasophila angulata and Leptacinus formicetorum are predators, actively seeking out early developmental stages of ants (eggs and larvae) and other invertebrates inhabiting nests of red wood ants. They can 
also scavenge dead bodies of adult ants and other insects in the anthill [2,21]. What is more, T. angulate adapts its behavior to avoid ants aggression or to defend when attacked [21,22]. Dendrophilus pygmaeus (Histeridae) is carnivorous, feeding on insect remains or dead ants. It is classified as a synechthran. Convex shape and hard exoskeleton, as well as the ability to conceal its antennae and legs (e.g., fovea antennalis as a morphological adaptation), allow them to avoid various ant attacks [23]. Monotoma angusticollis (Monotomidae) is a typical scavenger that feeds on animal food, such as dead ants or ants' prey [2]. This myrmecophile is a small, slow-moving beetle, which retracts its legs when attacked, making it difficult to detect [9]. Ptenidium formicetorum (Ptiliidae) is a very small beetle, which feeds on animal food and probably hunts small mites or springtails, commonly occurring in the nests of red wood ants. The last studies species, Myrmechixenus subterraneus (Tenebrionidae), is a well-known Euro-Siberian species, common in the nests of Formica ant species. It is also included in the synechthran category [24].

The presented study aimed to define the microbiome profiles of selected myrmecophiles and their host F. polyctena using the Next Generation Sequencing of the 16S rRNA gene. The bacterial communities were screened to establish the presence of known endosymbionts and bacterial groups that may be related to the adaptations to the conditions prevailing in the nest.

\section{Materials and Methods}

\subsection{Sample Collection}

Samples were collected as part of a research project on the fauna of myrmecophilous beetles inhabiting nests of the red wood ant F. polyctena in the Polesie National Park (Poland). The permission for field studies has been granted by the Ministry of the Environment, Poland (permission nos. DLP-III.286.148.2016.MGr and DLP-III.286.141.2016.MGr).

Specimens were collected during the summer and autumn of 2017. Monotoma angusticollis $(\mathrm{n}=5)$, Ptenidium formicetorum $(\mathrm{n}=17)$, Leptacinus formicetorum $(\mathrm{n}=4)$, and F. polyctena $(\mathrm{n}=20)$ were collected from the nest near the Dlugie Lake (N 51 $27^{\prime} 04.0^{\prime \prime}$ E $\left.23^{\circ} 09^{\prime} 39.9^{\prime \prime}\right)$. Myrmechixenus subterraneus ( $\left.\mathrm{n}=15\right)$, Thiasophila angulate $(\mathrm{n}=6)$, Dendrophilus pygmaeus $(\mathrm{n}=3)$ as well as the second sample of $F$. polyctena $(\mathrm{n}=20)$ were collected from a nest near the Lipniak village ( $51^{\circ} 27^{\prime} 51.2^{\prime \prime}$ E $\left.23^{\circ} 06^{\prime} 53.5^{\prime \prime}\right)$.

Approximately three liters of the nest material was taken from a depth of 20-30 cm and then densified using a standard entomological sieve. The obtained nest material, along with the live insects found, was placed in cloth pouches and transferred to the laboratory. Species were identified by the authors, according to particular insect identification keys [25-30]. Selected myrmecophiles were extracted from the substrate using a Tullgren funnel and were then stored at $-30^{\circ} \mathrm{C}$. Afterward, within 1-2 days after collecting, the tubes containing the insects were sent in dry ice to the Department of Genetics and Biosystematics, the University of Gdansk, where they were stored at $-70{ }^{\circ} \mathrm{C}$ until further analysis.

\subsection{DNA Extraction}

DNA was extracted from whole insects using a universal Sherlock AX Purification Kit (A\&A Biotechnology, Gdynia, Poland) based on spin column technology. Insects were rinsed three times in sterile distilled water prior to DNA extraction (without soaking in ethanol). Sterile equipment was used to avoid cross-contamination of samples. The quantity and quality of the extracted DNA were evaluated by using a NanoDrop ND-1000 spectrophotometer (NanoDrop Technologies Inc., Wilmington, Delaware, USA). After extraction, the DNA was stored at $-20{ }^{\circ} \mathrm{C}$ until further use.

\section{3. $16 S$ rRNA Gene Amplification and Sequencing}

Twenty-four samples consisting of specimens from six myrmecophilous beetles and red wood ants from two nests were used for further analyses (three individuals per species or nest). Negative controls have not been included. The V3-V4 hypervariable regions of the bacterial $16 \mathrm{~S}$ rRNA 
gene were amplified using the following primer set: 341F (CCTACGGGNGGCWGCAG) and 785R (GACTACHVGGGTATCTAATCC). Libraries were prepared with a two-step PCR protocol based on Illumina's "16S metagenomic library prep guide" (15044223 Rev. B), NEBNext ${ }^{\circledR}$ Q5 Hotstart High-Fidelity DNA polymerase (New England BioLabs Inc., Ipswich, MA, USA), according to the manufacturer's protocol using Q5 ${ }^{\circledR}$ Hot Start High-Fidelity 2X Master Mix (NEBNext-New England BioLabs, PCR conditions were as follows: $98{ }^{\circ} \mathrm{C}$ for $30 \mathrm{~s}$ for initial denaturation, $98^{\circ} \mathrm{C}$ for $10 \mathrm{~s}, 55^{\circ} \mathrm{C}$ for $30 \mathrm{~s}, 72{ }^{\circ} \mathrm{C}$ for $20 \mathrm{~s}$ repeated for 25 cycles that was followed by a final extension at $72{ }^{\circ} \mathrm{C}$ for $2 \mathrm{~min}$ ), and the Nextera Index kit $(2 \times 250 \mathrm{bp})$. Paired-end (PE, 2x250nt) sequencing with a 5\% PhiX spike-in was performed with an Illumina MiSeq (MiSeq Reagent kit v2) at Genomed, Warsaw, Poland, following the manufacturer's run protocols (Illumina, Inc., San Diego, CA, USA). The automatic primary analysis and the de-multiplexing of the raw reads were performed with MiSeq with the use of MiSeq Reporter (MSR) v2.6 (16S Metagenomics Protocol).

The data obtained for the independent sequencing were analyzed separately. Samples were marked as follows: DP- $L-D$. pygmaeus, LF-D—L. formicetorum, MA-D-M. angusticollis, MS- $L-M$. subterraneus, PF-D-P. formicetorum, TA- $L-T$. angulata, and FP-D and FP- $L$ for F. polyctena. Indices D and $\mathrm{L}$ refer to the sampling sites (Dlugie Lake or Lipniak village, respectively).

The samples were processed and analyzed using the Quantitative Insights Into Microbial Ecology (QIIME, version 1.9.1) pipeline [31]. Paired-end reads from MiSeq sequencing were quality trimmed and joined with PANDAseq version 2.8 [32] with a quality threshold of 0.9. The sequences that did not meet the quality criteria were removed from further analysis (mean quality $>20$ ). Chimeric reads detection was performed with VSEARCH, version 1.7.0, an open-source replacement of USEARCH software. The clustering of operational taxonomic units (OTUs) at $97 \%$ similarity was performed by using the uclust method, version 1.2.22q [33]. Sample reads were rarefied to 8253 reads. OTUs were assigned to taxa using the SILVA v.132 database as the reference [34], with the taxonomy assignment tool PyNAST [35]. OTU saturation was evaluated with rarefaction curves using the Chao1 richness estimate. The Biological Observation Matrix (BIOM) table was used as the core data for downstream analyses [36]. Any sequences that were classified as Mitochondria or Chloroplast, as well as the singletons, were filtered out of the dataset. The alpha diversity indices, including Shannon, and Simpson indices and also the observed OTUs were estimated for each sample. The bacterial community structure was compared with the use of UniFrac [37] and Emperor [38]. A two-dimensional principal coordinate analysis (PCoA) was conducted from weighted UniFrac distances obtained from core diversity analyses. To determine if observed clusters were significantly dissimilar, an analysis of similarity (ANOSIM) was performed in QIIME with 999 permutations.

Similarity percentage (SIMPER) analysis was performed to calculate the average dissimilarities in bacterial community structures between samples and to access which family was responsible for the observed differences. For this purpose, all profiles were grouped according to the taxonomic position of the host. According to the Diss/SD values, we identified families, which were primarily responsible for the observed differences among profiles (larger number means more consistently contributes to the dissimilarity between profiles). Relative abundances of those bacterial families, which were primarily responsible for differences between samples, were then used for a proximity analysis (non-metric Multidimensional Scaling, nMDS). A similarity profile (SIMPROF) test was used to identify well-defined groups of samples [39]. Finally, to illustrate the most abundant bacterial families and microbiome relationships across tested samples, a heatmap and dendrogram were generated with the Bray-Curtis dissimilarity index. All statistical multivariate analyses were performed using Primer version 7 software [40].

The NGS data are deposited and fully available under study accession number PRJEB31343 in ENA—the European Nucleotide Archive. 


\section{Results}

\subsection{General Description of $16 S$ rRNA Gene Sequencing Results}

More than 8200 good quality sequences were obtained for each sample tested, ranging between 8253 (T. angulata, specimen TA1-L) and 150,363 (F. polyctena, specimen FP2-D). Chao1 curves almost reached a plateau, suggesting that the sequencing was approximately deep (Figure S1). At least 29 OTUs, ranging from 29-723, were observed in tested samples. High values of the Chao1 index and a number of identified OTUs, as well as high values of Shannon's and Simpson's indices, were observed for all tested DP-L specimens (D. pygmaeus), which suggests the high alpha diversity of those communities. More details of the sequence data for each species, as well as the number of observed OTUs and alpha diversity indices, are given in Table S1.

\subsection{Bacterial Community Composition}

Analysis of the microbial communities associated with the tested species showed that all the assigned reads were affiliated with Bacteria (Table S1). At the phylum level, at least 99.82\% of all those sequences were classifiable, and the taxonomy-based analysis showed that the bacterial communities consisted of a total of 23 phyla (Figure 1 and Figure S2, Table S1). Proteobacteria, Actinobacteria, and Firmicutes were the most abundant phyla. They were observed in all samples tested and jointly accounted for more than $41 \%$ of the total microbial sequences obtained (in the range from $41.38 \%$ to $99.99 \%$ ). The remaining reads in bacterial structure were associated with Acidobacteria, Armatimonadetes, Bacteroidetes, Chlamydiae, Chloroflexi, Cyanobacteria, Deinococcus-Thermus, Dependentiae, Epsilonbacteraeota, FBP, Fusobacteria, Gemmatimonadetes, Hydrogenedentes, Nitrospirae, Patescibacteria, Planctomycetes, Rokubacteria, Tenericutes, Verrucomicrobia, and WSP-2, with different contributions to the population (Figure 1, Table S1).

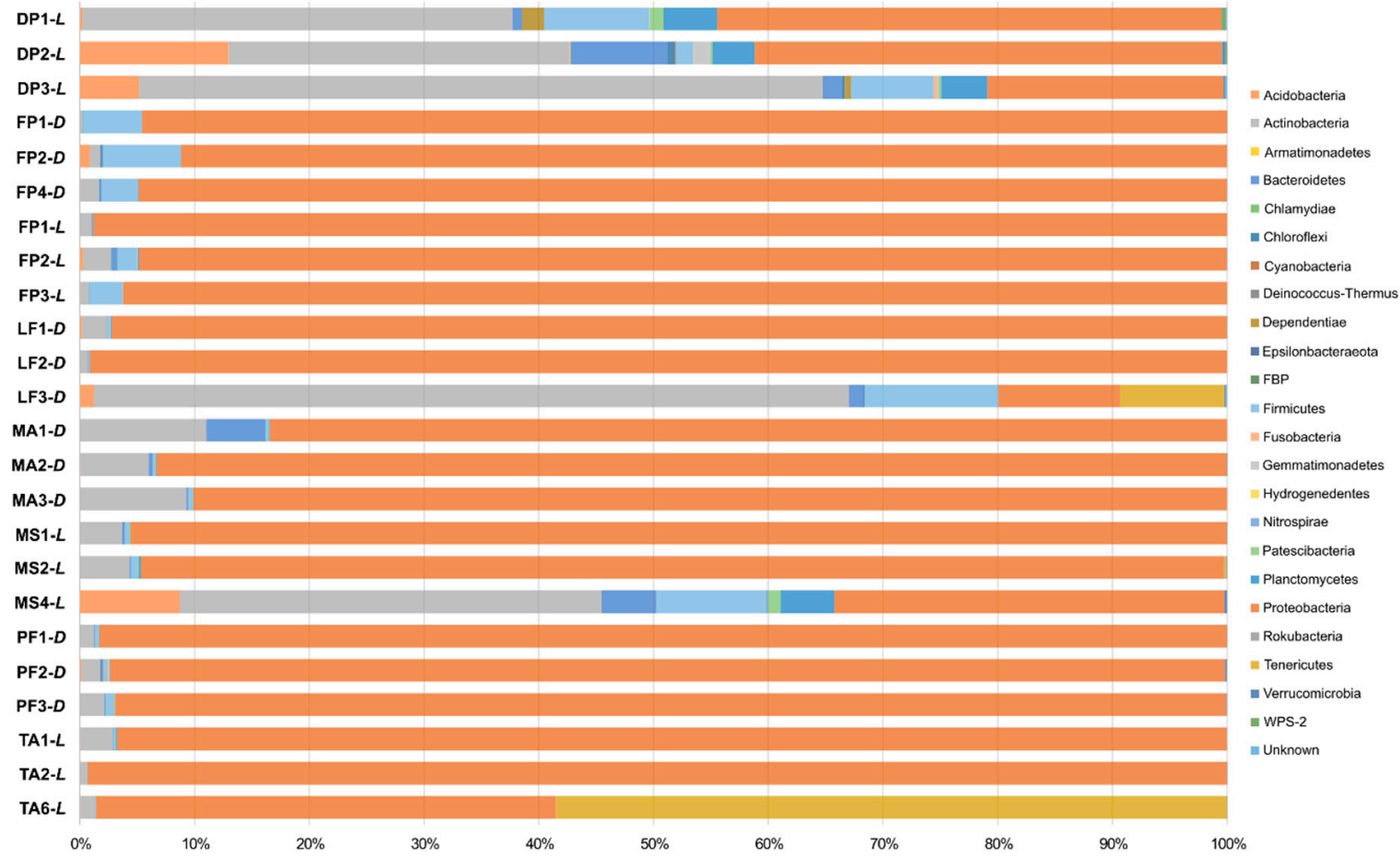

Figure 1. Abundance of bacterial 16S rRNA gene sequences at the phylum level.

Relative abundances of identified bacterial groups at lower levels have been presented in interactive sunburst charts (Figure S2). The most numerous bacterial groups at lower taxonomic levels include: Alphaproteobacteria, Actinobacteria, Gammaproteobacteria, Planctomycetacia, and Bacilli at the 
class level and Rickettsiales, Corynebacteriales, Rhisobiales, Propionibacteriales, Streptomycethases, Acidobacteriales, and Betaproteobacteriales at the order level.

At the family level, Anaplasmataceae and Rickettsiaceae were generally the most abundant. However, the analysis of SIMPER results revealed that 16 families were primarily responsible for the observed differences among samples. Their relative abundances were indicated on the heatmap (Figure 2). All samples tested were clustered into five groups and three outliers by the SIMPROF test $(p<0.05$; Figure 2). Five samples (DP1- $L$, DP2- $L$, DP3- $L$, LF3- $D$, and MS4- $L$ ) clustered together and were characterized, for example, by less abundant Anaplasmataceae, and more abundant Streptomycetaceae and Propionibacteriaceae. Bacterial communities associated with $M$. angusticollis also clustered together and were characterized by more abundant Enterobacteriaceae and Tsukamurellaceae (Figure S3).

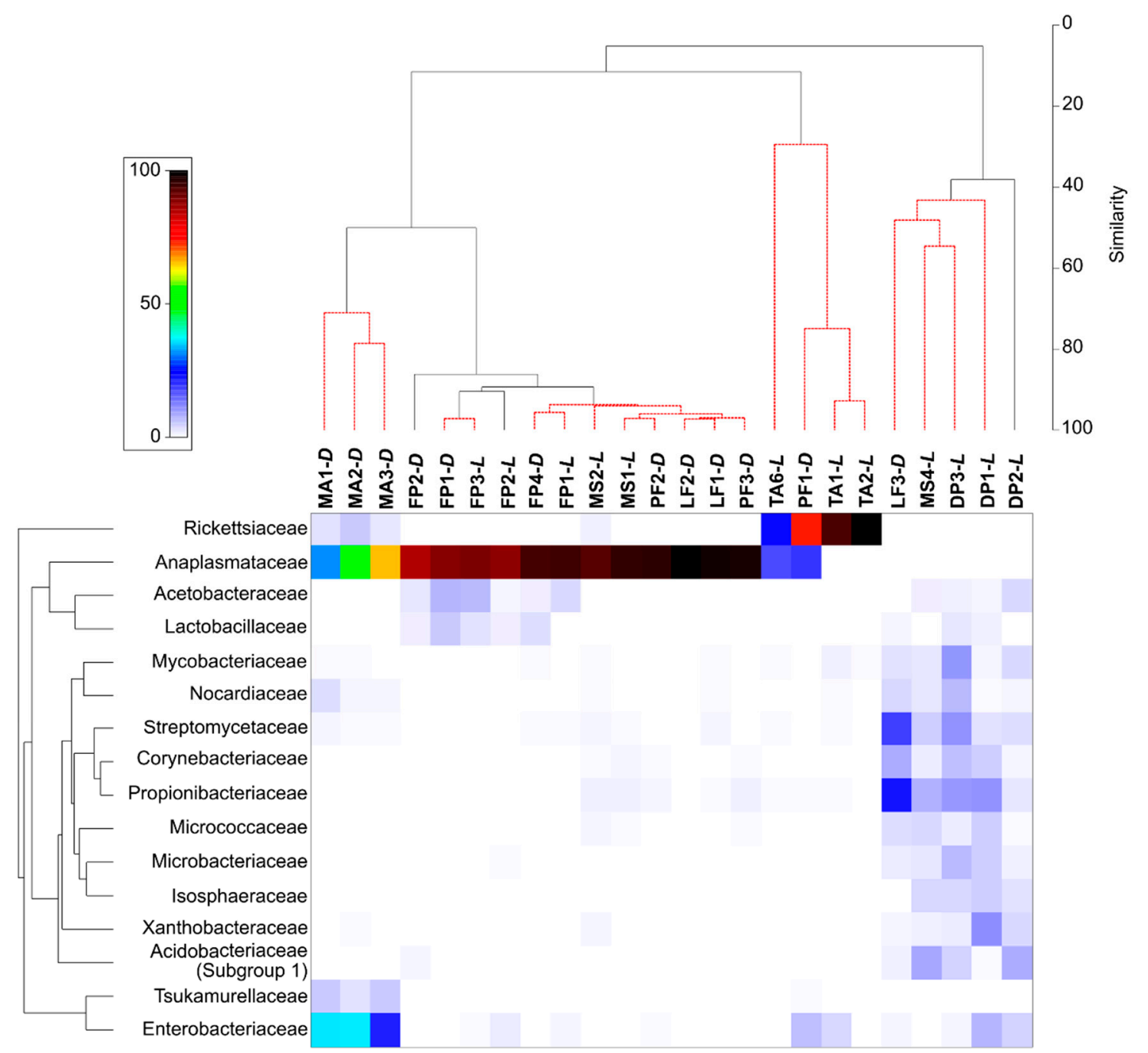

Figure 2. The heatmap showing bacterial families distributed across tested samples. Only those families who were primarily responsible for the observed differences among samples were considered. Both dendrograms were estimated with the Bray-Curtis dissimilarity index.

PCoA plot reveals that samples generally grouped into three distinct clusters (ANOSIM: $R=0.91$, $p=0.001$ ), which was congruent with SIMPROF results at lower levels of similarity of microbiota profiles (about 20\%) (Figure 3A). Bacterial communities associated with F. polyctena (both from Dlugie Lake and Lipniak), M. subterraneus (except MS4-L), L. formicetorum (except LF3-D), and P. formicetorum (except PF1-D) were the most similar and clustered together. Nonparametric MDS analysis ( $85 \%$ similarity) 
revealed three vectors (Anaplasmataceae, Rickettsiaceae, and Isosphaeraceae), which allowed for distinguishing among clusters (Figure 3B).

A

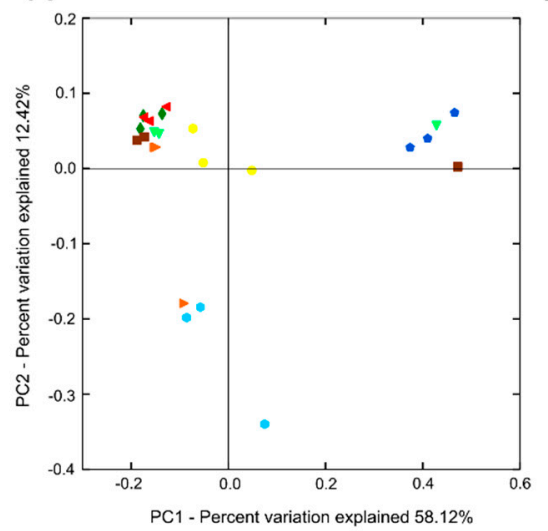

B

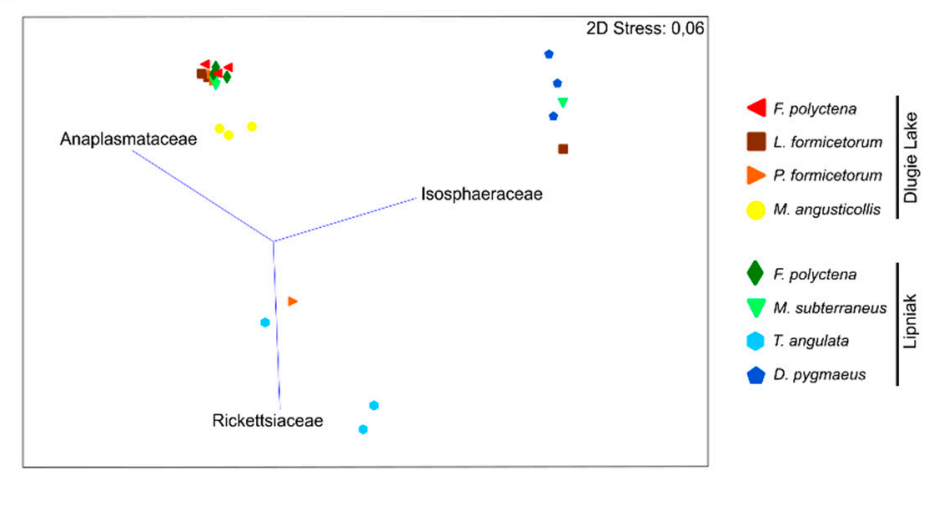

Figure 3. Principal Coordinate Analysis (PCoA) and Non-metric Multidimensional Scaling (nMDS) plots of the tested samples. (A) PCOA of bacterial communities associated with tested specimens based on weighted UniFrac distances; (B) nMDS based on Bray-Curtis dissimilarity between samples with identified vectors allowing to distinguish among clusters. Both plots show high overlap among F. polyctena, L. formicetorum, P. formicetorum, and M. angusticollis samples.

Analysis at the genus-level revealed that Wolbachia and Rickettsia are the most abundant genera (Figure S2, Table S1). The highest relative abundance of Wolbachia has been noticed for L. formicetorum (98.75\% in LF2-D). In the case of T. angulata, Rickettsia was more abundant than Wolbachia and accounted in the range of $22.63 \%$ for TA6- $L$ to $99.01 \%$ for TA2- $L$ (Figure S2, Table S1). Only in bacterial communities associated with D. pygmaeus, the relative abundances of those two endosymbionts did not exceed $1.00 \%$.

We could not a priori exclude that high relative abundance of Wolbachia and Rickettsia hid a host-specific sorting of analyzed microbiome profiles. To test this hypothesis, all analyses were repeated without Wolbachia and Rickettsia reads in the dataset. PCoA plot revealed that bacterial communities associated with F. polyctena differ from those associated with selected myrmecophiles (PERMANOVA: Pseudo-F $=7.7561, p=0.001$ ) (Figure $4 \mathrm{~A}$ ). That finding has been also supported by the result of a SIMPROF analysis that grouped all F. polyctena profiles in a homogenous cluster (Figure 4B). Values of ANOSIM calculated for pair-wise comparisons were significant only for pairs including F. polyctena $(\mathrm{R}=0.846-0.994, p=0.01)$.

In all bacterial communities associated with ants, a higher relative abundance of Lactobacillaceae and Acetobacteraceae have been identified compared to other profiles tested (Diss/SD values calculated in SIMPER analysis were 1.44 and 1.73, respectively) (Figure 4B). In the case of bacterial communities associated with selected myrmecophiles, a species-specific separation has not been found and SIMPER analysis revealed that the abundance of Propionibacteriaceae and Streptomycetaceae make those profiles similar (calculated values of Sim/SD ware 0.93 and 0,75, respectively). Despite this general similarity of microbiota profiles associated with selected myrmecophiles, for L. formicetorum, M. angusticollis, and F. polyctena, the average similarity of profiles within species was higher than between species pair (calculated with PERMANOVA pair-wise test; Table 1). Nevertheless, only for M. angusticollis (MA1-D-MA3-D), we were able to connect this result with higher abundance of Enterobacteriaceae in its profiles (but profiles remained similar to P. formicetorum PF1-D profile and T. angulata TA1- $L$ profile). The profiles separation according to the locality of the host's nest has not been identified. (ANOSIM: $\mathrm{R}=0.001, p=0.366)$. 


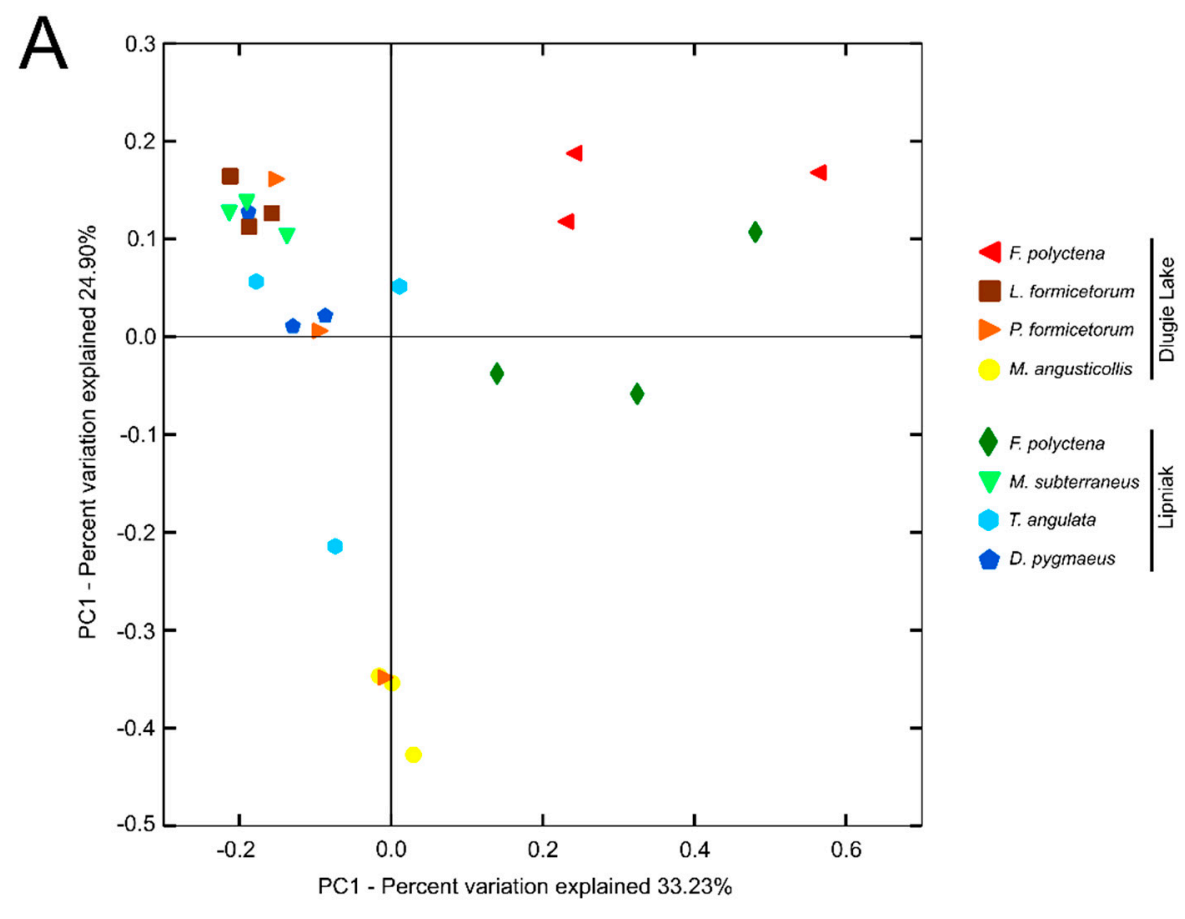

\section{B}
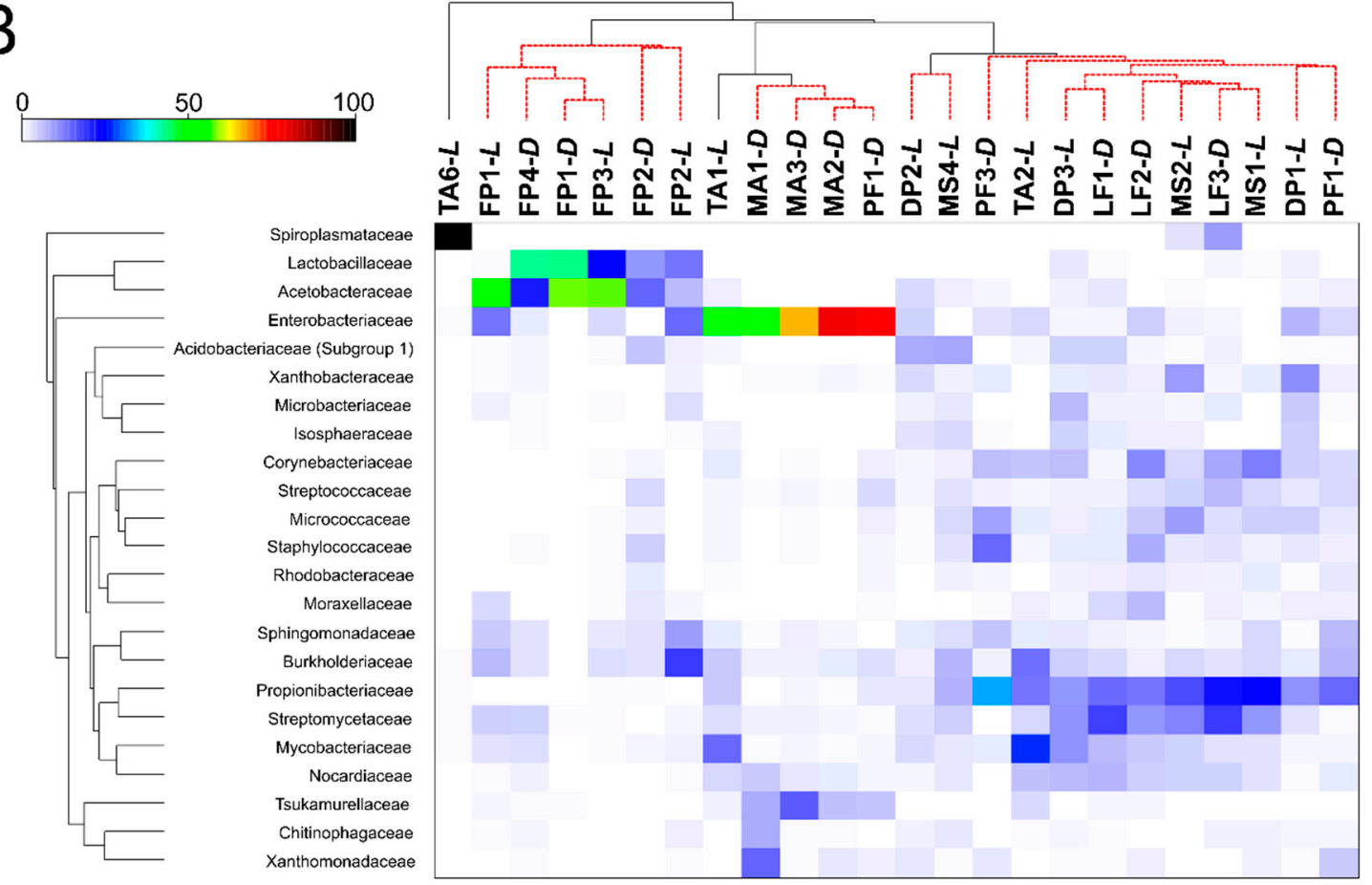

Figure 4. Principal Coordinate Analysis (PCoA) plot and the heatmap showing relationships among tested microbiome profiles after filtering Wolbachia and Rickettsia reads out. (A) PCoA of bacterial communities associated with tested specimens based on weighted UniFrac distances; (B) the heatmap showing bacterial families distributed across tested samples. Only those families who were primarily responsible for the observed differences among samples were considered. Both dendrograms were estimated with the Bray-Curtis dissimilarity index. 
Table 1. Average similarity between and within groups of identified microbiota profiles. Profiles were grouped according to host species.

\begin{tabular}{cccccccc}
\hline Host Species & $\begin{array}{c}\text { D. } \\
\text { pygmaeus }\end{array}$ & $\begin{array}{c}\boldsymbol{F} . \\
\text { polyctena }\end{array}$ & $\begin{array}{c}\text { L. } \\
\text { formicetorum }\end{array}$ & $\begin{array}{c}\text { M. } \\
\text { angusticollis }\end{array}$ & $\begin{array}{c}\text { M. } \\
\text { subterraneus }\end{array}$ & $\begin{array}{c}\text { P. } \\
\text { formicetorum }\end{array}$ & $\begin{array}{c}\text { T. } \\
\text { angulata }\end{array}$ \\
\hline D. pygmaeus & 51.066 & & & & & & \\
F. polyctena & 22.568 & 48.954 & & & & & \\
L. formicetorum & 51.785 & 17.534 & 65.864 & & & & \\
M. angusticollis & 16.151 & 11.77 & 13.216 & 77.465 & & & \\
M. subterraneus & 53.743 & 18.352 & 62.895 & 11.372 & 58.866 & & \\
P. formicetorum & 35.998 & 16.628 & 40.068 & 35.943 & 43.313 & 33.288 & 18.352 \\
T. angulata & 28.933 & 13.482 & 30.611 & 27.323 & 28.206 & 26.899 & \\
\hline
\end{tabular}

\section{Discussion}

Specialized interactions of bacterial communities with insect hosts are ubiquitous and often beneficial to insects [41]. Nevertheless, those communities may vary from simple to complex and can be influenced by environmental, genetic, and other factors of the host or host's environment (e.g., host diet, phylogeny (coevolution), life stage, host location or $\mathrm{pH}$ ) [42-47]. For many hosts, their phylogeny and diet have a strong effect on associated bacterial communities [48-50].

Although many studies have been focused on revealing the bacterial communities associated with insects, especially social species (e.g., [45,51-59]), still relatively little is known about potential similarities and differences among microbiomes of invertebrates, which are closely associated with ants. The study presented here gave the first insight into the bacterial population structure of $F$. polyctena and six unspecialized myrmecophilous beetle species commonly inhabiting its nests [19,20]. Identified microbiome profiles were compared with available data obtained for other known myrmecophiles and their hosts. Nevertheless, it is worth mentioning that such studies are limited and myrmecophiles from five families selected here have not been included in them previously.

Microbiota analyses bear a risk of sample contamination. Thus, it is reasonable to analyze additional negative and positive samples, which was pointed out by Hornung et al. (2019) [60]. Although we did not use negative controls in obtaining libraries, we have made every effort to minimize the risk of contamination. We found that all tested bacterial communities were predominated by three phyla (Proteobacteria, Actinobacteria, and Firmicutes), with each comprising a different share of the microbiome depending on species or sample tested (Table S1). Those phyla are frequently listed as the most abundant in bacterial communities associated with insect taxa [61-64], including ants [49,65-70] and myrmecophilous caterpillars of Lycaenidae butterflies [71-73]. In some cases, the joint abundance of those phyla may exceed even $90 \%$ of bacterial community membership [63]. Such high values were also observed in the presented study. However, for most samples, only Proteobacteria was predominant. That phylum has also been identified as a significant part of the bacterial communities associated with the leaf-cutting ants genera Atta and Acromyrmex [65], the plant-ant genera Allomerus and Tetraponera [74], the turtle ant Cephalotes rohweli [67] or the weaver ant Oecophylla smaragdina [75]. Interestingly, for D. pygmaeus samples, Proteobacteria was less abundant $(<44 \%)$ and Actinobacteria was more frequently identified than in the rest of bacterial communities tested $(>29 \%)$ (Table S1).

The high relative abundance of Actinobacteria and Proteobacteria could be explained through the prism of previous studies. Members of Actinobacteria are able to protect different insect species (e.g., ants and beetles) from pathogens by excretion of substances with antibiotic activity [76]. In our study, Pseudonocardia and Streptomyces have been found (Table S1). Those beneficial bacteria are reared especially by higher fungus-farming ants and housed in their cuticular crypts, tubercles, and other modifications associated with subcuticular exocrine glands [77]. Both Pseudonocardia and Streptomyces are known to produce antibiotic substances and protect nests and their hosts against numerous bacterial and fungal microbes [78-80]. These metabolites are primarily active against Escovopsis, a potentially virulent, specialized fungus that attacks the ants' mutualistic fungus [77,81]. In addition, 
antibiotics from these bacteria, together with the metapleural gland, contribute to ants' immune system against their pathogens [65]. Although F. polyctena and selected myrmecophiles are not involved in fungus farming, their food resources and brood are constantly in contact with the soil and prone to fungal invasion. Therefore, the protective role of identified Actinobacteria in the host-myrmecophile relationship seems likely. Such activity has been described previously in studies on bacteria associated with other ant species, also Formica representatives $[65,74,76,82-86]$.

In the case of Proteobacteria, the explanation seems to be different. Those bacteria are known to be metabolically versatile or specialized and therefore adapted to complex environments, such as the gut of social insects [87]. Therefore, their high abundance in almost all tested samples should not raise suspicions. In bacterial communities associated with $F$. polyctena we found an increased abundance of Acetobacteraceae (Figure 4B). Members of this family have been identified in microbiome profiles of ants feeding on carbohydrate-rich diets, including honeydew-feeding Camponotus carpenter ants, Formica wood ants, Linepithema Argentine ants [88-90], and numerous insect species relying on sugar-based diets [91,92]. That increased abundance may be primarily related to the presence of the honeydew in the F. polyctena diet. However, the acetic acid bacteria (AAB) have also been shown to actively colonize different insect tissues and organs and being involved in the regulation of the innate immune system homeostasis [93].

Although members of the Acetobacteraceae family were abundant in microbiome profiles of F. polyctena, all tested bacterial communities were primarily predominated by other Proteobacteria members-Anaplasmataceae and Rickettsiaceae (Table S1, Figure S2). The predominance of those two families has been directly connected with a high relative abundance of Wolbachia and Rickettsia endosymbionts. The former potentially infects more than $65 \%$ of insect species $[94,95]$ and a wide range of ant genera, for example, Atta and Acromyrmex [96-98], Camponotus [99,100], Cephalotes [101,102], Colobopsis [103], Formica [104,105], Polyrhachis [49], Solenopsis [106-108], and others [109-111]. Wolbachia has been also identified with high relative abundance in bacterial communities associated with the myrmecophilous larvae of Maculinea alcon butterfly [71]. As Wolbachia could well represent the most widespread symbiont in insects, it remains at the center of researchers' interests. This endosymbiont acts like a detrimental reproductive manipulator because it can cause the cytoplasmic incompatibility, parthenogenesis, male killing, or male feminization [112-115]. There are also examples showing that Wolbachia protects its host against RNA viruses [116,117]. However, its function in ants is unknown, especially in the sterile workers, who are not able to reproduce [118-120]. On the other hand, some evidence suggests that Wolbachia may influence sex ratios of these social insects [110].

Nevertheless, the identification of Wolbachia endosymbiont may raise the question about its potential horizontal transmission among F. polyctena and selected myrmecophiles. This phenomenon may occur very frequently in ants and has been described previously by Reuter et al. (2005) [121] for three ant genera Linepithema, Acromyrmex, and Solenopsis located in Latin America. However, a recent study showed that not all Wolbachia strains associated with ants have the same genetic potential for horizontal transmission [122]. Here, we cannot unambiguously state whether endosymbiont is horizontally transmitted among F. polyctena and associated myrmecophiles. However, this hypothesis seems likely, because all specimens share the same identified OTUs. At this stage of research, we cannot exclude both direct and indirect transfer. The direct horizontal transfer has been discussed by Dedeine et al. (2005) [123] who investigated Wolbachia variants infecting fly parasitoids, inquiline social parasite Solenopsis daguerrei, and their hosts (Solenopsis invicta and S. richteri, respectively), revealing identical symbiont variants shared among $S$. daguerrei and both its hosts. Interaction between the social parasite and its host (such as trophallaxis, egg carrying, or brood feeding) may provide opportunities for the transmission of Wolbachia from the host to the social parasite and the other way around [123]. Myrmecophiles, of which microbiome profiles were analyzed in the present study, may acquire endosymbiont in a similar way. As predators and scavengers, they feed on dead hosts or their brood, which may constitute the infection source. The other possible transmission way may be environmentally-mediated. Such examples have been noted, for example, in intertidal amphipod 
crustaceans or butterflies sharing the same habitat [124,125]. Moreover, a recent study has also confirmed the possibility of horizontal transmission through food sources [126,127].

Although all hypotheses mentioned above seem likely, the reason for the lack of infection in D. pygmaeus and T. angulata remains unsolved. Both species feed on dead ants or their brood and live in close relationships with F. polyctena, which would allow expecting that Wolbachia will be present in their microbiome profiles as well. However, the results presented here have been obtained for limited samples, and therefore, we cannot exclude that both D. pygmaeus and T. angulata are infected with Wolbachia in a smaller percentage than the other selected species. Moreover, we cannot unambiguously reject the possibility that native microbiota of these two myrmecophiles impede Wolbachia transmission. Such observations have been described previously for Anopheles mosquitoes [128].

The second known endosymbiotic Proteobacteria member found here with a higher relative abundance was Rickettsia. Like Wolbachia, Rickettsia can also influence the biology of its insect hosts. As vertically transmitted endosymbiont, it is known to have diverse effects on hosts, ranging from influencing host fitness to manipulating its reproduction [129]. Recent studies have shown that Rickettsia-containing populations are more tolerant of heat shock than those without this endosymbiont [130]. Rickettsia-infected species can also produce more offspring, have a greater survival rate to adulthood, develop faster, and produce a higher proportion of female offspring [131]. Moreover, the presence of Rickettsia can be linked to host protection against entomopathogenic bacteria, for example, Pseudomonas syringae [132] or a higher level of susceptibility to insecticides [117].

In the present study, Rickettsia has been identified in bacterial communities associated with six selected beetle species, comprising a different share of the microbiome depending on the beetle host. However, Rickettsia was not found in F. polyctena bacterial communities. A similar result has been obtained for another Formica ant, F. cinerea [133]. In the case of selected beetles, the highest values of Rickettsia abundance have been observed for T. angulata (range from 22.63 for TA6- $L$ to $99.01 \%$ for TA2- $L$ ). In the rest of the tested microbiome profiles that endosymbiont counted for was less than $5 \%$ (Table S1). Interestingly, in microbial communities of M. angusticollis (MA1-D-MA3-D), P. formicetorum (PF1-D) and T. angulata (TA6-L) Rickettsia coexist with Wolbachia, which was identified previously for other beetles [134-136].

The variation in microbiota in insects is related to many factors. The microbial community can be determined by the host phylogeny, gut morphology, and physic-chemical conditions, such as $\mathrm{pH}$ and oxygen availability in the insect gut $[137,138]$. These and other factors (e.g., developmental stage and diet) were also identified shaping ants' microbiota $[47,49,103,139,140]$. In the present study, the bacterial communities associated with selected insects have been influenced also by insects' dietary habits and other unrevealed biotic or abiotic factors. However, the indirect aim of the presented study was to identify a diagnostic and universal microbiome profile that would be characteristic for myrmecophiles inhabiting F. polyctena nests and belonging to the same trophic level. Such a study has been performed previously for predatory and herbivorous ant species [48]. Nevertheless, the relationships among the microbiome profiles identified here were complex, and no relative abundance pattern that would be common to all species was observed. Bacterial communities associated with most selected species (except D. pygmaeus, $M$. angusticollis, and T. angulata) cluster together, but the observed similarities are rather the results of Wolbachia infection than the common microbiome pattern. This trend has been shown in Figure 3B, where Anaplasmataceae is identified as one of the main grouping vectors. Some subtle, species-specific patterns have been observed for bacterial communities associated with $D$. pygmaeus, M. angusticollis, and T. angulata (Figure 1). Filtering out Wolbachia and Rickettsia reads from the analyzed dataset revealed that all F. polyctena samples cluster together (Figure 3B), and further analyses revealed that Lactobacillaceae and Acetobacteraceae were primarily responsible for observed similarity. In the case of bacterial communities associated with selected beetles, SIMPER analysis revealed that Propionibacteriaceae and Streptomycetaceae are generally more abundant in them. However, ANOSIM and PERMANOVA tests did not support the presence of more complex, species-specific sorting, and sample separation according to the locality of the host's nest. Thus, at this stage of the 
study, we cannot identify a common and stable microbiota profile, which would be characteristic for myrmecophilous beetles.

\section{Conclusions}

This paper presents the results of the case study and analyses of bacterial communities associated with F. polyctena and six myrmecophilous beetles inhabiting its nests. The host phylogeny does not directly affect the composition of the microbiome. Most of the analyzed microbiome profiles were clustering together, but it might be strictly correlated with a high relative abundance of Wolbachia reads. This endosymbiont has been previously identified for F. polyctena, but here, we identified its occurrence in the microbiome profiles of six myrmecophilous beetles for the first time. Furthermore, for all species except F. polyctena, the Rickettsia endosymbiosis has been identified. However, after filtering out Wolbachia and Rickettsia reads, we revealed that bacterial communities associated with F. polyctena differ from those associated with selected myrmecophiles. Nevertheless, microbiota profiles of selected myrmecophiles were not homogenous.

Supplementary Materials: The following are available online at http://www.mdpi.com/2075-4450/11/2/134/s1, Figure S1: Rarefaction curves with Chao1 diversity indices, indicating insect microbiome sampling depth and saturation, Figure S2: Detailed taxonomic analyses at different ranks for DNA. Sunburst charts show the relative abundance of microbial $16 \mathrm{~S}$ rDNA sequences at different taxonomic levels. The first level represents the kingdom; the second level represents all phyla present in a particular sample; subsequent next levels represent the class, order, family and genus, Figure S3: Relative abundances of bacterial families primarily responsible for observed differences among profiles, Table S1: Sheet 1 -Summary of the sequencing data and statistical analysis of bacterial communities associated with F. polyctena and selected myrmecophilous beetles. Sheets 2-6-Detailed taxonomic analyses at different ranks with the data obtained for the samples tested. The table shows the relative abundance of microbial 16S rDNA sequences at different taxonomic levels.

Author Contributions: Conceptualization, A.K.-Z. and B.S.; methodology, A.K.-Z.; validation, A.K.-Z.; formal analysis, A.K.-Z.; investigation, A.K.-Z., M.Z., G.K.W. and E.P.-T.; resources, A.K.-Z., M.Z., G.K.W., E.P.-T. and B.S.; writing —original draft preparation, A.K.-Z.; writing—review and editing, A.K.-Z., M.Z., G.K.W., E.P.-T. and B.S.; visualization, A.K.-Z.; supervision, B.S.; funding acquisition, B.S. All authors have read and agreed to the published version of the manuscript.

Funding: This research was funded by the State Forests National Forest Holding, Poland and the Polesie National Park, Poland, grant numbers EZ.0290.1.28.2017 and NB 520-3/2017.

Acknowledgments: We are grateful to the Center for Medical Genomics-OMICRON for their advice.

Conflicts of Interest: The authors declare no conflict of interest. The funders had no role in the design of the study; in the collection, analyses, or interpretation of data; in the writing of the manuscript, or in the decision to publish the results.

\section{References}

1. Kronauer, D.J.C.; Pierce, N.E. Myrmecophiles. Curr. Biol. 2011, 21, 208-209. [CrossRef] [PubMed]

2. Parmentier, T.; Bouillon, S.; Dekoninck, W.; Wenseleers, T. Trophic interactions in an ant nest microcosm: A combined experimental and stable isotope $(\delta 13 C / \delta 15 N)$ approach. Oikos 2016, 1182-1192. [CrossRef]

3. Parker, J. Myrmecophily in beetles (Coleoptera): Evolutionary patterns and biological mechanisms. Myrmecol. News 2016, 22, 65-108.

4. Mynhardt, G. Declassifying myrmecophily in the coleoptera to promote the study of ant-beetle symbioses. Psyche 2013. [CrossRef]

5. Staniec, B.; Pietrykowska-Tudruj, E.; Zagaja, M. Adaptive External Larval Ultrastructure of Lomechusa Gravenhorst, 1806 (Coleoptera: Staphylinidae: Aleocharinae), an Obligate Myrmecophilous Genus. Ann. Zool. 2017, 67, 609-626. [CrossRef]

6. O'Keefe, S.T. Ant-Like Stone Beetles, Ants, and Their Associations (Coleoptera: Scydmaenidae; Hymenoptera: Formicidae; Isoptera). J. N. Y. Entomol. Soc. 2000, 108, 273-303. [CrossRef]

7. Päivinen, J.; Ahlroth, P.; Kaitala, V. Ant-associated beetles of Fennoscandia and Denmark. Entomol. Fenn. 2002, 13, 20-40. [CrossRef]

8. Kaminski, L.A.; Carvalho-Filho, F.S. Life History of Aricoris propitia (Lepidoptera: Riodinidae)-A Myrmecophilous Butterfly Obligately Associated with Fire Ants. Psyche 2012, 2012, 1-10. [CrossRef] 
9. Parmentier, T.; Dekoninck, W.; Wenseleers, T. A highly diverse microcosm in a hostile world: A review on the associates of red wood ants (Formica rufa group). Insectes Soc. 2014, 61, 229-237. [CrossRef]

10. Robertson, J.A.; Moore, W. Phylogeny of Paussus L. (Carabidae: Paussinae): Unravelling morphological convergence associated with myrmecophilous life histories. Syst. Entomol. 2017, 42, 134-170. [CrossRef]

11. Ivens, A.B.F.; Gadau, A.; Kiers, E.T.; Kronauer, D.J.C. Can social partnerships influence the microbiome? Insights from ant farmers and their trophobiont mutualists. Mol. Ecol. 2018, 27, 1898-1914. [CrossRef] [PubMed]

12. Liberti, J.; Sapountzis, P.; Hansen, L.H.; Sørensen, S.J.; Adams, R.M.M.; Boomsma, J.J. Bacterial symbiont sharing in Megalomyrmex social parasites and their fungus-growing ant hosts. Mol. Ecol. 2015, 24, 3151-3169. [CrossRef] [PubMed]

13. Véle, A.; Holuša, J.; Frouz, J. Ecological requirements of some ant species of the genus Formica (Hymenoptera, Formicidae) in spruce forests. J. For. Sci. 2009, 55, 32-40. [CrossRef]

14. Bernasconi, C.; Cherix, D.; Seifert, B.; Pamilo, P. Molecular taxonomy of the Formica rufa group (red wood ants) (Hymenoptera: Formicidae): A new cryptic species in the Swiss Alps? Myrmecol. News 2010, 14, $37-47$.

15. Gosswald, K. The wood ant. Volume 2. The wood ant in the forest ecosystem, its uses and protection. In Die Waldameise. Band 2. Die Waldameise Okosystem Wald, ihr Nutzen und ihre Hege; AULA: Wiesbaden, Germany, 1989.

16. Bernasconi, C.; Pamilo, P.; Cherix, D. Genetic differentiation of disjunct populations of the ants Formica aquilonia and Formica lugubris in Europe. Insectes Soc. 1992, 39, 15-29. [CrossRef]

17. Goropashnaya, A.V.; Fedorov, V.B.; Pamilo, P. Recent speciation in the Formica rufa group ants (Hymenoptera, Formicidae): Inference from mitochondrial DNA phylogeny. Mol. Phylogenet. Evol. 2004, 32, 198-206. [CrossRef]

18. Stockan, J.A.; Robinson, E.J.H. Wood Ant Ecology and Conservation; Cambridge University Press: Cambridge, UK, 2016; ISBN 9781107261402.

19. Staniec, B.; Zagaja, M. Rove-beetles (Coleoptera, Staphylinidae) of ant nests of the vicinities of Leżajsk. Ann. UMCS Biol. 2008, 63, 111-127. [CrossRef]

20. Härkönen, S.K.; Sorvari, J. Species richness of associates of ants in the nests of red wood ant Formica polyctena (Hymenoptera, Formicidae). Insect Conserv. Divers. 2014, 7, 485-495. [CrossRef]

21. Zagaja, M.; Staniec, B.; Pietrykowska-Tudruj, E.; Trytek, M. Biology and defensive secretion of myrmecophilous Thiasophila spp. (Coleoptera: Staphylinidae: Aleocharinae) associated with the Formica rufa species group. J. Nat. Hist. 2017, 51, 2759-2777. [CrossRef]

22. Parmentier, T.; De Laender, F.; Wenseleers, T.; Bonte, D. Prudent behavior rather than chemical deception enables a parasite to exploit its ant host. Behav. Ecol. 2018, 29, 1225-1233. [CrossRef]

23. Mazur, S. Część XIX Chrzaszzcze-Coleoptera, zeszyt 11-12, Sphaeritidae i gniliki-Histeridae; Klucze do.; Państwowe Wydawnictwo Naukowe: Warszawa, Poland, 1973.

24. Shavrin, A.V.; Anichtchenko, A.V.; Barsevskis, A. Contribution to the knowledge of myrmecophilous beetles (Coleoptera) of Latvia. Linzer Biol. Beiträge 2015, 47, 1829-1842.

25. Assing, V.; Schülke, M. Freude-Harde-Lohse-Klausnitzer-Die Käfer Mitteleuropas. Band 4. Staphylinidae I. Zweite neubearbeitete Auflage; Spektrum Akademischer Verlag, I-XII: Heidelberg, Germany, 2011.

26. Besuchet, C. Ptiliidae. Die Kafer Mitteleuropus, 3. Krefeld; Freude, H., Harde, K.W., Lohse, G.A., Eds.; Goecke und Evers: Krefeld, Germany, 1971; pp. 311-334.

27. Freude, H.; Harde, K.; Lohse, W. Die Käfer Mitteleuropas. Bd. 5. Staphylinidae II (Hypocyphtinae und Aleocharinae), Pselaphidae; Goecke und Evers Verlag: Krefeld, Germany, 1974.

28. Stebnicka, Z. Chrzaszcze-Coleoptera, Czarnuchowate-Tenebrionidae, Boridae; Klucze do Oznaczania Owadów Polski, cz. XIX: Wroclaw, Poland, 1991.

29. Ślipiński, S. Chrzaszzze-Coleoptera, Monotomidae; Klucze do Oznaczania Owadów Polski, cz. XIX: Wroclaw, Poland, 1981.

30. Witzgall, K. Histeridae. In Die Käfer Mitteleuropas. Bd. 3; Freude, H., Harde, K.W., Lohse, G.A., Eds.; Goecke \& Evers Verlag: Krefeld, Germany, 1971; pp. 156-189.

31. Caporaso, J.G.; Kuczynski, J.; Stombaugh, J.; Bittinger, K.; Bushman, F.D.; Costello, E.K.; Fierer, N.; Gonzalez Pena, A.; Goodrich, J.K.; Gordon, J.I.; et al. QIIME allows analysis of high-throughput community sequencing data. Nat. Methods 2010, 7, 335-336. [CrossRef] [PubMed] 
32. Masella, A.P.; Bartram, A.K.; Truszkowski, J.M.; Brown, D.G.; Naufeld, J.D. PANDAseq: Paired-end assembler for illumina sequences. BMC Bioinform. 2012, 13, 31. [CrossRef] [PubMed]

33. Edgar, R.C. Search and clustering orders of magnitude faster than BLAST. Bioinformatics 2010, 26, 2460-2461. [CrossRef]

34. Quast, C.; Pruesse, E.; Yilmaz, P.; Gerken, J.; Schweer, T.; Yarza, P.; Peplies, J.; Glöckner, F.O. The SILVA ribosomal RNA gene database project: Improved data processing and web-based tools. Nucleic Accids Res. 2013, 41, D590-D596. [CrossRef] [PubMed]

35. Caporaso, J.G.; Bittinger, K.; Bushman, F.; DeSantis, T.; Andersen, G.; Knight, R. PyNAST: A flexible tool for aligning sequences to a template alignment. Bioinformatics 2010, 26, 266-267. [CrossRef]

36. McDonald, D.; Clemente, J.C.; Kuczynski, J.; Rideout, J.R.; Stombaugh, J.; Wendel, D.; Wilke, A.; Huse, S.; Hufnagle, J.; Meyer, F.; et al. The Biological Observation Matrix (BIOM) format or: How I learned to stop worrying and love the ome-ome. Gigascience 2012, 1, 1-6. [CrossRef]

37. Lozupone, C.; Knight, R. UniFrac: A new phylogenetic method for comparing microbial communities. Appl. Environ. Microbiol. 2005, 71, 8228-8235. [CrossRef]

38. Vázquez-Baeza, Y.; Pirrung, M.; Gonzalez, A.; Knight, R. EMPeror: A tool for visualizing high-throughput microbial community data. Gigascience 2013, 26, 2-16. [CrossRef]

39. Clarke, K.R.; Somerfield, P.J.; Gorley, R.N. Testing of null hypotheses in exploratory community analyses: Similarity profiles and biota-environment linkage. J. Exp. Mar. Biol. Ecol. 2008, 366, 56-69. [CrossRef]

40. Clarke, K.R.; Gorley, R. PRIMER version 7: User manual/tutorial. Available online: http://updates.primer-e. com/primer7/manuals/Getting_started_with_PRIMER_7.pdf (accessed on 1 December 2019).

41. Duron, O.; Hurst, G.D. Arthropods and inherited bacteria: From counting the symbionts to understanding how symbionts count. BMC Biol. 2013, 11, 45. [CrossRef] [PubMed]

42. Santo Domingo, J.W.; Kaufman, M.G.; Klug, M.J.; Holben, W.E.; Harris, D.; Tiedje, J.M. Influence of diet on the structure and function of the bacterial hindgut community of crickets. Mol. Ecol. 1998, 7, 761-767. [CrossRef]

43. Schmitt-Wagner, D.; Friedrich, M.W.; Wagner, B.; Brune, A. Axial Dynamics, Stability, and Interspecies Similarity of Bacterial Community Structure in the Highly Compartmentalized Gut of Soil-Feeding Termites (Cubitermes spp.). Appl. Environ. Microbiol. 2003, 69, 6018-6024. [CrossRef] [PubMed]

44. Hongoh, Y.; Deevong, P.; Inoue, T.; Moriya, S.; Trakulnaleamsai, S.; Ohkuma, M.; Vongkaluang, C.; Noparatnaraporn, N.; Kudo, T. Intra-and interspecific comparisons of bacterial diversity community structure support co-evolution of gut microbiota and termite host. Appl. Environ. Microbiol. 2005, 71, 6590-6599. [CrossRef] [PubMed]

45. Mohr, K.I.; Tebbe, C.C. Diversity and phylotype consistency of bacteria in the guts of three bee species (Apoidea) at an oilseed rape field. Environ. Microbiol. 2006, 8, 258-272. [CrossRef] [PubMed]

46. Behar, A.; Yuval, B.; Jurkevitch, E. Community Structure of the Mediterranean Fruit Fly Microbiota: Seasonal and Spatial Sources of Variation. Isr. J. Ecol. Evol. 2008, 54, 181-191. [CrossRef]

47. Ramalho, M.O.; Moreau, C.S.; Bueno, O.C. The Potential Role of Environment in Structuring the Microbiota of Camponotus across Parts of the Body. Adv. Entomol. 2019, 7, 47-70. [CrossRef]

48. Anderson, K.E.; Russell, J.A.; Moreau, C.S.; Kautz, S.; Sullam, K.E.; Hu, Y.; Basinger, U.; Mott, B.M.; Buck, N.; Wheeler, D.E. Highly similar microbial communities are shared among related and trophically similar ant species. Mol. Ecol. 2012, 21, 2282-2296. [CrossRef]

49. Ramalho, M.O.; Bueno, O.C.; Moreau, C.S. Microbial composition of spiny ants (Hymenoptera: Formicidae: Polyrhachis) across their geographic range. BMC Evol. Biol. 2017, 17, 96. [CrossRef]

50. Sanders, J.G.; Powell, S.; Kronauer, D.J.C.; Vasconcelos, H.L.; Frederickson, M.E.; Pierce, N.E. Stability and phylogenetic correlation in gut microbiota: Lessons from ants and apes. Mol. Ecol. 2014, 23, 1268-1283. [CrossRef]

51. Tholen, A.; Schink, B.; Brune, A. The gut microflora of Reticulitermes flavipes, its relation to oxygen, and evidence for oxygen-dependent acetogenesis by the most abundant Enterococcus sp. FEMS Microbiol. Ecol. 2006, 24, 137-149. [CrossRef]

52. Cox-Foster, D.L.; Conlan, S.; Holmes, E.C.; Palacios, G.; Evans, J.D.; Moran, N.A.; Quan, P.L.; Briese, T.; Hornig, M.; Geiser, D.M.; et al. A Metagenomic Survey of Microbes in Honey Bee Colony Collapse Disorder. Science 2007, 318, 283-287. [CrossRef] [PubMed] 
53. Russell, J.A.; Goldman-Huertas, B.; Moreau, C.S.; Baldo, L.; Stahlhut, J.K.; Werren, J.H.; Pierce, N.E. Specialization and geographic isolation among Wolbachia symbionts from ants and lycaenid butterflies. Evolution 2009, 63, 624-640. [CrossRef] [PubMed]

54. Funaro, C.F.; Kronauer, D.J.C.; Moreau, C.S.; Goldman-Huertas, B.; Pierce, N.E.; Russell, J.A. Army ants harbor a host-specific clade of Entomoplasmatales bacteria. Appl. Environ. Microbiol. 2011, 77, 346-350. [CrossRef] [PubMed]

55. Martinson, V.G.; Danforth, B.N.; Minckley, R.L.; Rueppell, O.; Tingek, S.; Moran, N.A. A simple and distinctive microbiota associated with honey bees and bumble bees. Mol. Ecol. 2011, 20, 619-628. [CrossRef] [PubMed]

56. Engel, P.; Martinson, V.G.; Moran, N.A.; Robinson, G.E. Functional diversity within the simple gut microbiota of the honey bee. Proc. Natl. Acad. Sci. USA 2012, 109, 11002-11007. [CrossRef]

57. Köhler, T.; Dietrich, C.; Scheffrahn, R.H.; Brune, A. High-Resolution Analysis of Gut Environment and Bacterial Microbiota Reveals Functional Compartmentation of the Gut in Wood-Feeding Higher Termites (Nasutitermes spp.). Appl. Environ. Microbiol. 2012, 78, 4691-4701. [CrossRef]

58. Poulsen, M.; Sapountzis, P. Behind every great ant, there is a great gut. Mol. Ecol. 2012, 21, $2054-2057$. [CrossRef]

59. Su, L.; Yang, L.; Huang, S.; Su, X.; Li, Y.; Wang, F.; Wang, E.; Kang, N.; Xu, J.; Song, A. Comparative Gut Microbiomes of Four Species Representing the Higher and the Lower Termites. J. Insect Sci. 2016, 16, 1-9. [CrossRef]

60. Hornung, B.V.H.; Zwittink, R.D.; Kuijper, E.J. Issues and current standards of controls in microbiome research. FEMS Microbiol. Ecol. 2019, 95, 1-7. [CrossRef]

61. Colman, D.R.; Toolson, E.C.; Takacs-Vesbach, C.D. Do diet and taxonomy influence insect gut bacterial communities? Mol. Ecol. 2012, 21, 5124-5137. [CrossRef] [PubMed]

62. Jones, R.T.; Sanchez, L.G.; Fierer, N. A cross-taxon analysis of insect-associated bacterial diversity. PLoS ONE 2013, 8, e61218. [CrossRef] [PubMed]

63. Yun, J.H.; Roh, S.W.; Whon, T.W.; Jung, M.J.; Kim, M.S.; Park, D.S.; Yoon, C.; Nam, Y.D.; Kim, Y.J.; Choi, J.H.; et al. Insect Gut Bacterial Diversity Determined by Environmental Habitat, Diet, Developmental Stage, and Phylogeny of Host. Appl. Environ. Microbiol. 2014, 80, 5254-5264. [CrossRef] [PubMed]

64. Kim, J.M.; Choi, M.Y.; Kim, J.W.; Lee, S.A.; Ahn, J.H.; Song, J.; Kim, S.H.; Weon, H.Y. Effects of diet type, developmental stage, and gut compartment in the gut bacterial communities of two Cerambycidae species (Coleoptera). J. Microbiol. 2017, 55, 21-30. [CrossRef] [PubMed]

65. Vieira, A.S.; Ramalho, M.O.; Martins, C.; Martins, V.G.; Bueno, O.C. Microbial Communities in Different Tissues of Atta sexdens rubropilosa Leaf-cutting Ants. Curr. Microbiol. 2017, 74, 1216-1225. [CrossRef] [PubMed]

66. Kellner, K.; Ishak, H.D.; Linksvayer, T.A.; Mueller, U.G. Bacterial community composition and diversity in an ancestral ant fungus symbiosis. FEMS Microbiol. Ecol. 2015, 91, 1-10. [CrossRef] [PubMed]

67. Lanan, M.C.; Rodrigues, P.A.P.; Agellon, A.; Jansma, P.; Wheeler, D.E. A bacterial filter protects and structures the gut microbiome of an insect. ISME J. 2016, 10, 1866-1876. [CrossRef]

68. Meirelles, L.A.; McFrederick, Q.S.; Rodrigues, A.; Mantovani, J.D.; De Melo Rodovalho, C.; Ferreira, H.; Bacci, M.; Mueller, U.G. Bacterial microbiomes from vertically transmitted fungal inocula of the leaf-cutting ant Atta texana. Environ. Microbiol. Rep. 2016, 8, 630-640. [CrossRef]

69. Scott, J.J.; Budsberg, K.J.; Suen, G.; Wixon, D.L.; Balser, T.C.; Currie, C.R. Microbial community structure of leaf-cutter ant fungus gardens and refuse dumps. PLoS ONE 2010, 5, e9922s. [CrossRef]

70. Sapountzis, P.; Zhukova, M.; Hansen, L.H.; Sørensen, S.J.; Schiøtt, M.; Boomsma, J.J. Acromyrmex leaf-cutting ants have simple gut microbiota with nitrogen-fixing potential. Appl. Environ. Microbiol. 2015, 81, 5527-5537. [CrossRef]

71. Di Salvo, M.; Calcagnile, M.; Talà, A.; Tredici, S.M.; Maffei, M.E.; Schönrogge, K.; Barbero, F.; Alifano, P. The Microbiome of the Maculinea-Myrmica Host-Parasite Interaction. Sci. Rep. 2019, 9, 1-10. [CrossRef] [PubMed]

72. Whitaker, M.R.L.; Salzman, S.; Sanders, J.; Kaltenpoth, M.; Pierce, N.E. Microbial communities of lycaenid butterflies do not correlate with larval diet. Front. Microbiol. 2016, 7, 1-13. [CrossRef] [PubMed] 
73. Szenteczki, M.A.; Pitteloud, C.; Casacci, L.P.; Kešnerová, L.; Whitaker, M.R.L.; Engel, P.; Vila, R.; Alvarez, N. Bacterial communities within Phengaris (Maculinea) alcon caterpillars are shifted following transition from solitary living to social parasitism of Myrmica ant colonies. Ecol. Evol. 2019, 9, 4452-4464. [CrossRef] [PubMed]

74. Seipke, R.F.; Org Barke, J.; Heavens, D.; Yu, D.W.; Hutchings, M.I. Analysis of the bacterial communities associated with two ant-plant symbioses. Microbiol. Open 2013, 2, 276-283. [CrossRef]

75. Chua, K.O.; Song, S.L.; Yong, H.S.; See-Too, W.S.; Yin, W.F.; Chan, K.G. Microbial Community Composition Reveals Spatial Variation and Distinctive Core Microbiome of the Weaver Ant Oecophylla smaragdina in Malaysia. Sci. Rep. 2018, 8, 1-11. [CrossRef]

76. Zakalyukina, Y.V.; Biryukov, M.V.; Golichenkov, M.V.; Netrusov, A.I. Phenotypic and phylogenetic characterization of actinomycetes isolated from Lasius niger and Formica cunicularia ants. Mosc. Univ. Biol. Sci. Bull. 2017, 72, 13-19. [CrossRef]

77. Currie, C.R.; Poulsen, M.; Mendenhall, J.; Boomsma, J.J.; Billen, J. Coevolved crypts and exocrine glands support mutualistic bacteria in fungus-growing ants. Science 2006, 311, 81-83. [CrossRef]

78. Sen, R.; Ishak, H.D.; Estrada, D.; Dowd, S.E.; Hong, E.; Mueller, U.G. Generalized antifungal activity and 454-screening of Pseudonocardia and Amycolatopsis bacteria in nests of fungus-growing ants. Proc. Natl. Acad. Sci. USA 2009, 106, 17805-17810. [CrossRef]

79. Mueller, U.G.; Scott, J.J.; Ishak, H.D.; Cooper, M.; Rodrigues, A. Monoculture of leafcutter ant gardens. PLOS ONE 2010, 5, 1-7. [CrossRef]

80. Zucchi, T.D.; Guidolin, A.S.; Consoli, F.L. Isolation and characterization of actinobacteria ectosymbionts from Acromyrmex subterraneus brunneus (Hymenoptera, Formicidae). Microbiol. Res. 2011, 166, 68-76. [CrossRef]

81. Currie, C.R.; Scott, J.A.; Summerbell, R.C.; Malloch, D. Fungus-growing ants use antibiotic-producing bacteria to control garden parasites. Nature 1999, 398, 701-704. [CrossRef]

82. Haeder, S.; Wirth, R.; Herz, H.; Spiteller, D. Candicidin-producing Streptomyces support leaf-cutting ants to protect their fungus garden against the pathogenic fungus Escovopsis. Proc. Natl. Acad. Sci. USA 2009, 106, 4742-4746. [CrossRef] [PubMed]

83. Barke, J.; Seipke, R.F.; Grüschow, S.; Heavens, D.; Drou, N.; Bibb, M.J.; Goss, R.J.; Yu, D.W.; Hutchings, M.I. A mixed community of actinomycetes produce multiple antibiotics for the fungus farming ant Acromyrmex octospinosus. BMC Biol. 2010, 8, 109. [CrossRef] [PubMed]

84. Schoenian, I.; Spiteller, M.; Ghaste, M.; Wirth, R.; Herz, H.; Spiteller, D. Chemical basis of the synergism and antagonism in microbial communities in the nests of leaf-cutting ants. Proc. Natl. Acad. Sci. USA 2011, 108, 1955-1960. [CrossRef]

85. Mattoso, T.C.; Moreira, D.D.O.; Samuels, R.I. Symbiotic bacteria on the cuticle of the leaf-cutting ant Acromyrmex subterraneus subterraneus protect workers from attack by entomopathogenic fungi. Biol. Lett. 2012, 8, 461-464. [CrossRef]

86. Matarrita-Carranza, B.; Moreira-Soto, R.D.; Murillo-Cruz, C.; Mora, M.; Currie, C.R.; Pinto-Tomas, A.A. Evidence for widespread associations between neotropical hymenopteran insects and Actinobacteria. Front. Microbiol. 2017, 8, 1-17. [CrossRef]

87. Esposti, M.D.; Romero, E.M. The functional microbiome of arthropods. PLoS ONE 2017, 12, e0176573. [CrossRef]

88. Russell, J.A.; Moreau, C.S.; Goldman-Huertas, B.; Fujiwara, M.; Lohman, D.J.; Pierce, N.E. Bacterial gut symbionts are tightly linked with the evolution of herbivory in ants. Proc. Natl. Acad. Sci. USA 2009, 106, 21236-21241. [CrossRef]

89. Brown, B.P.; Wernegreen, J.J. Deep divergence and rapid evolutionary rates in gut-associated Acetobacteraceae of ants. BMC Microbiol. 2016, 16, 1-17. [CrossRef]

90. Hu, Y.; Holway, D.A.; Łukasik, P.; Chau, L.; Kay, A.D.; LeBrun, E.G.; Miller, K.A.; Sanders, J.G.; Suarez, A.V.; Russell, J.A. By their own devices: Invasive Argentine ants have shifted diet without clear aid from symbiotic microbes. Mol. Ecol. 2017, 26, 1608-1630. [CrossRef]

91. Crotti, E.; Rizzi, A.; Chouaia, B.; Ricci, I.; Favia, G.; Alma, A.; Sacchi, L.; Bourtzis, K.; Mandrioli, M.; Cherif, A.; et al. Acetic acid bacteria, newly emerging symbionts of insects. Appl. Environ. Microbiol. 2010, 76, 6963-6970. [CrossRef] [PubMed]

92. Ashbolt, N.J.; Inkerman, P.A. Acetic acid bacterial biota of the pink sugar cane mealybug, Saccharococcus sacchari, and its environs. Appl. Environ. Microbiol. 1990, 56, 707-712. [CrossRef] [PubMed] 
93. Roh, S.W.; Nam, Y.D.; Chang, H.W.; Kim, K.H.; Kim, M.S.; Ryu, J.H.; Kim, S.H.; Lee, W.J.; Bae, J.W. Phylogenetic characterization of two novel commensal bacteria involved with innate immune homeostasis in Drosophila melanogaster. Appl. Environ. Microbiol. 2008, 74, 6171-6177. [CrossRef]

94. Hilgenboecker, K.; Hammerstein, P.; Schlattmann, P.; Telschow, A.; Werren, J.H. How many species are infected with Wolbachia? A statistical analysis of current data. FEMS Microbiol. Lett. 2008, 281, 215-220. [CrossRef] [PubMed]

95. Lewis, Z.; Lizé, A. Insect behaviour and the microbiome. Curr. Opin. Insect Sci. 2015, 9, 86-90. [CrossRef]

96. Frost, C.L.; Fernández-Marín, H.; Smith, J.E.; Hughes, W.O.H. Multiple gains and losses of Wolbachia symbionts across a tribe of fungus-growing ants. Mol. Ecol. 2010, 19, 4077-4085. [CrossRef]

97. Frost, C.L.; Pollock, S.W.; Smith, J.E.; Hughes, W.O.H. Wolbachia in the flesh: Symbiont intensities in germ-line and somatic tissues challenge the conventional view of Wolbachia transmission routes. PLoS ONE 2014, 9, e95122. [CrossRef]

98. Van Borm, S.; Wenseleers, T.; Billen, J.; Boomsma, J.J. Cloning and sequencing of wsp encoding gene fragments reveals a diversity of co-infecting Wolbachia strains in Acromyrmex leafcutter ants. Mol. Phylogenet. Evol. 2003, 26, 102-109. [CrossRef]

99. Ramalho, M.O.; Vieira, A.S.; Pereira, M.C.; Moreau, C.S.; Bueno, O.C. Transovarian Transmission of Blochmannia and Wolbachia Endosymbionts in the Neotropical Weaver Ant Camponotus textor (Hymenoptera, Formicidae). Curr. Microbiol. 2018, 75, 866-873. [CrossRef]

100. Ramalho, M.O.; Martins, C.; Silva, L.M.R.; Martins, V.G.; Bueno, O.C. Intracellular Symbiotic Bacteria of Camponotus textor, Forel (Hymenoptera, Formicidae). Curr. Microbiol. 2017, 74, 589-597. [CrossRef]

101. Reeves, D.D.; Price, S.L.; Ramalho, M.O.; Moreau, C.S. The Diversity and Distribution of Wolbachia, Rhizobiales, and Ophiocordyceps within the Widespread Neotropical Turtle Ant, Cephalotes atratus (Hymenoptera: Formicidae). Neotrop. Entomol. 2020. [CrossRef]

102. Kelly, M.; Price, S.L.; De Oliveira Ramalho, M.; Moreau, C.S. Diversity of Wolbachia Associated with the Giant Turtle Ant, Cephalotes atratus. Curr. Microbiol. 2019, 76, 1330-1337. [CrossRef] [PubMed]

103. Ramalho, M.O.; Bueno, O.C.; Moreau, C.S. Species-specific signatures of the microbiome from Camponotus and Colobopsis ants across developmental stages. PLoS ONE 2017, 12, e0187461. [CrossRef] [PubMed]

104. Keller, L.; Liautard, C.; Reuter, M.; Brown, W.D.; Sundström, L.; Chapuisat, M. Sex ratio and Wolbachia infection in the ant Formica exsecta. Heredity 2001, 87, 227-233. [CrossRef] [PubMed]

105. Viljakainen, L.; Reuter, M.; Pamilo, P. Wolbachia transmission dynamics in Formica wood ants. BMC Evol. Biol. 2008, 8, 55. [CrossRef] [PubMed]

106. Ishak, H.D.; Plowes, R.; Sen, R.; Kellner, K.; Meyer, E.; Estrada, D.A.; Dowd, S.E.; Mueller, U.G. Bacterial Diversity in Solenopsis invicta and Solenopsis geminata Ant Colonies Characterized by $16 \mathrm{~S}$ amplicon 454 Pyrosequencing. Microb. Ecol. 2011, 61, 821-831. [CrossRef] [PubMed]

107. Martins, C.; Souza, R.F.; Bueno, O.C. Presence and distribution of the endosymbiont Wolbachia among Solenopsis spp. (Hymenoptera: Formicidae) from Brazil and its evolutionary history. J. Invertebr. Pathol. 2012, 109, 287-296. [CrossRef]

108. Souza, R.F.; Martins, C.; Pereira, R.M.; Bueno, O.C. Analysis of the Hypervariable Regions (HVRs) of the wsp Gene of Wolbachia from Solenopsis invicta Ants in Southeastern Brazil. Adv. Entomol. 2014, 2, 135-143. [CrossRef]

109. Russell, J.A.; Funaro, C.F.; Giraldo, Y.M.; Goldman-Huertas, B.; Suh, D.; Kronauer, D.J.C.; Moreau, C.S.; Pierce, N.E. A veritable menagerie of heritable bacteria from ants, butterflies, and beyond: Broad molecular surveys and a systematic review. PLoS ONE 2012, 7, e51027. [CrossRef]

110. Pontieri, L.; Schmidt, A.M.; Singh, R.; Pedersen, J.S.; Linksvayer, T.A. Artificial selection on ant female caste ratio uncovers a link between female-biased sex ratios and infection by Wolbachia endosymbionts. J. Evol. Biol. 2017, 30, 225-234. [CrossRef]

111. Wenseleers, T.; Ito, F.; Van Borm, S.; Huybrechts, R.; Volckaert, F.; Billen, J. Widespread Occurrence of the Microorganism Wolbachia in Ants. Proc. Biol. Sci. 1998, 265, 1447-1452. [CrossRef] [PubMed]

112. Stouthamer, R.; Breeuwer, J.A.J.; Hurst, G.D.D. Wolbachia Pipientis: Microbial Manipulator of Arthropod Reproduction. Annu. Rev. Microbiol. 1999, 53, 71-102. [CrossRef] [PubMed]

113. Charlat, S.; Hurst, G.D.D.; Merçot, H. Evolutionary consequences of Wolbachia infections. Trends Genet. 2003, 19, 217-223. [CrossRef] 
114. Correa, C.C.; Ballard, J.W.O. Wolbachia Associations with Insects: Winning or Losing Against a Master Manipulator. Front. Ecol. Evol. 2016, 3, 1-18. [CrossRef]

115. Pietri, J.E.; Debruhl, H.; Sullivan, W. The rich somatic life of Wolbachia. Microbiol. Open 2016, 5, 923-936. [CrossRef]

116. Hedges, L.M.; Brownlie, J.C.; O'neill, S.L.; Johnson, K.N. Wolbachia and Virus Protection in Insects. Science 2008, 322, 702. [CrossRef]

117. Goodacre, S.L.; Martin, O.Y. Modification of Insect and Arachnid Behaviours by Vertically Transmitted Endosymbionts: Infections as Drivers of Behavioural Change and Evolutionary Novelty. Insects 2012, 3, 246-261. [CrossRef]

118. Andersen, S.B.; Boye, M.; Nash, D.R.; Boomsma, J.J. Dynamic Wolbachia prevalence in Acromyrmex leaf-cutting ants: Potential for a nutritional symbiosis. J. Evol. Biol. 2012, 25, 1340-1350. [CrossRef]

119. Russell, J.A.; Sanders, J.G.; Moreau, C.S. Hotspots for symbiosis: Function, evolution, and specificity of ant-microbe associations from trunk to tips of the ant phylogeny (Hymenoptera: Formicidae). Myrmecol. News 2017, 24, 43-69.

120. Russell, J.A. The ants (Hymenoptera: Formicidae) are unique and enigmatic hosts of prevalent Wolbachia (Alphaproteobacteria) symbionts. Myrmecol. News 2012, 16, 7-23.

121. Reuter, M.; Pedersen, J.S.; Keller, L. Loss of Wolbachia infection during colonisation in the invasive Argentine ant Linepithema humile. Heredity 2005, 94, 364-369. [CrossRef] [PubMed]

122. Tolley, S.J.A.; Nonacs, P.; Sapountzis, P. Wolbachia Horizontal Transmission Events in Ants: What Do We Know and What Can We Learn? Front. Microbiol. 2019, 10, 1-9. [CrossRef] [PubMed]

123. Dedeine, F.; Ahrens, M.; Calcaterra, L.; Shoemaker, D.D. Social parasitism in fire ants (Solenopsis spp.): A potential mechanism for interspecies transfer of Wolbachia. Mol. Ecol. 2005, 14, 1543-1548. [CrossRef] [PubMed]

124. Cordaux, R.; Michel-Salzat, A.; Bouchon, D. Wolbachia infection in crustaceans: Novel hosts and potential routes for horizontal transmission. J. Evol. Biol. 2001, 14, 237-243. [CrossRef]

125. Dyson, E.A.; Kamath, M.K.; Hurst, G.D.D. Wolbachia infection associated with all-female broods in Hypolimnas bolina (Lepidoptera: Nymphalidae): Evidence for horizontal transmission of a butterfly male killer. Heredity 2002, 88, 166-171. [CrossRef]

126. Li, S.J.; Ahmed, M.Z.; Lv, N.; Shi, P.Q.; Wang, X.M.; Huang, J.L.; Qiu, B.L. Plantmediated horizontal transmission of Wolbachia between whiteflies. ISME J. 2017, 11, 1019-1028. [CrossRef]

127. Kajtoch, Ł.; Kotásková, N. Current state of knowledge on Wolbachia infection among Coleoptera: A systematic review. Peer J. 2018, 6, e4471. [CrossRef]

128. Hughes, G.L.; Dodson, B.L.; Johnson, R.M.; Murdock, C.C.; Tsujimoto, H.; Suzuki, Y.; Patt, A.A.; Cui, L.; Nossa, C.W.; Barry, R.M.; et al. Native microbiome impedes vertical transmission of Wolbachia in Anopheles mosquitoes. Proc. Natl. Acad. Sci. USA 2014, 111, 12498-12503. [CrossRef]

129. Giorgini, M.; Bernardo, U.; Monti, M.M.; Nappo, A.G.; Gebiola, M. Rickettsia symbionts cause parthenogenetic reproduction in the parasitoid wasp Pnigalio soemius (Hymenoptera: Eulophidae). Appl. Environ. Microbiol. 2010, 76, 2589-2599. [CrossRef]

130. Brumin, M.; Kontsedalov, S.; Ghanim, M. Rickettsia influences thermotolerance in the whitefly Bemisia tabaci B biotype. Insect Sci. 2011, 18, 57-66. [CrossRef]

131. Himler, A.G.; Adachi-Hagimori, T.; Bergen, J.E.; Kozuch, A.; Kelly, S.E.; Tabashnik, B.E.; Chiel, E.; Duckworth, V.E.; Dennehy, T.J.; Zchori-Fein, E.; et al. Rapid spread of a bacterial symbiont in an invasive whitefly is driven by fitness benefits and female bias. Science 2011, 332, 254-256. [CrossRef] [PubMed]

132. Hendry, T.A.; Hunter, M.S.; Baltrus, D.A. The Facultative Symbiont Rickettsia Protects an Invasive Whitefly against Entomopathogenic Pseudomonas syringae Strains. Appl. Environ. Microbiol. 2014, 80, 7161-7168. [CrossRef] [PubMed]

133. Sirviö, A.; Pamilo, P. Multiple endosymbionts in populations of the ant Formica cinerea. BMC Evol. Biol. 2010, 10, 335. [CrossRef] [PubMed]

134. Weinert, L.A.; Tinsley, M.C.; Temperley, M.; Jiggins, F.M. Are we underestimating the diversity and incidence of insect bacterial symbionts? A case study in ladybird beetles. Biol. Lett. 2007, 3, 678-681. [CrossRef]

135. White, J.A.; Richards, N.K.; Laugraud, A.; Saeed, A.; Curry, M.M.; McNeill, M.R. Endosymbiotic Candidates for Parasitoid Defense in Exotic and Native New Zealand Weevils. Microb. Ecol. 2015, 70, 274-286. [CrossRef] 
136. Perotti, A.M.; Young, D.K.; Braig, H.R. The ghost sex-life of the paedogenetic beetle Micromalthus debilis. Sci. Rep. 2016, 6, 1-10. [CrossRef]

137. Dillon, R.J.; Dillon, V.M. The Gut Bacteria of Insects: Nonpathogenic Interactions. Annu. Rev. Entomol. 2004, 49, 71-92. [CrossRef]

138. Engel, P.; Moran, N.A. The gut microbiota of insects-diversity in structure and function. FEMS Microbiol. Rev. 2013, 37, 699-735. [CrossRef]

139. Hu, Y.; Łukasik, P.; Moreau, C.S.; Russell, J.A. Correlates of gut community composition across an ant species (Cephalotes varians) elucidate causes and consequences of symbiotic variability. Mol. Ecol. 2014, 23, 1284-1300. [CrossRef]

140. Rubin, B.E.R.; Kautz, S.; Wray, B.D.; Moreau, C.S. Dietary specialization in mutualistic acacia-ants affects relative abundance but not identity of host-associated bacteria. Mol. Ecol. 2019, 28, 900-916. [CrossRef]

(C) 2020 by the authors. Licensee MDPI, Basel, Switzerland. This article is an open access article distributed under the terms and conditions of the Creative Commons Attribution (CC BY) license (http://creativecommons.org/licenses/by/4.0/). 